$\begin{array}{r}\text { Volume and Issues Obtainable at Center for Sustainability Research and Consultancy } \\ \text { Review of Politics and Public Policy in Emerging Economies } \\ \text { ISSN: 2708-3829 (E): 2708-356X } \\ \text { Volume 1: No. 2, December 2019 } \\ \text { CSRᄃ } \\ \text { Journal homepage: www.publishing.globalcsrc.org/rope } \\ \hline\end{array}$

\title{
Candidate Selection and the Electoral Prospects of the Peoples' Democratic Party (PDP) in Nigeria: 1999-2015
}

\author{
${ }^{1}$ Alfa Patrick Innocent, ${ }^{2}$ Otaida Eikojonwa \\ ${ }^{1}$ Department of Social Science and Humanities, The Federal Polytechnic, Kogi State, Nigeria \\ alfaintellectual@gmail.com \\ Department of Political Science, Federal University Dutsin Ma, Katsina State, Nigeria \\ otaidaeikojonwa@gmail.com
}

\begin{tabular}{|c|c|}
\hline ARTICLE DETAILS & ABSTRACT \\
\hline $\begin{array}{l}\text { History } \\
\text { Revised format: November } 2019 \\
\text { Available Online: December } 2019 \\
\text { Keywords } \\
\text { Candidate selection, } \\
\text { political parties, Peoples' } \\
\text { Democratic Party, election, } \\
\text { internal party democracy } \\
\text { JEL Classification: } \\
\text { H50, H59 }\end{array}$ & $\begin{array}{l}\text { Objective: This article intends to ascertain the centrality, or otherwise, of } \\
\text { candidate selection in the electoral fortunes of the Peoples' Democratic } \\
\text { Party (PDP) in Nigeria from } 1999 \text { to } 2015 \text {. } \\
\text { Methodology: This paper is qualitative and conceptual in nature. The } \\
\text { issues were analyzed under various related themes. The data were } \\
\text { gathered through the secondary method which includes textbooks, journal } \\
\text { publications, party constitutions, the Electoral Acts and the } 1999 \\
\text { Constitution of the Federal Republic of Nigeria. The analysis of the } \\
\text { information gathered revealed the factors that determined the electoral } \\
\text { vicissitudes of the Peoples' Democratic Party (PDP) from } 1999 \text { to } 2015 \text {. } \\
\text { Results: The paper unveiled that interferences and manipulation in the } \\
\text { candidate selection procedures in particular and overall gross disregard for } \\
\text { the tenets of internal party democracy in the Peoples' Democratic Party } \\
\text { led to its electoral misfortunes in the } 2015 \text { elections. } \\
\text { Implication: The paper avers that political parties are fundamental } \\
\text { elements in any democratic setting, but for them to retain and boost their } \\
\text { electoral chances they must adopt a transparent candidate selection process, } \\
\text { as well as observe and promote the principles of internal party democracy. }\end{array}$ \\
\hline OPEN & $\begin{array}{r}\text { (C) } 2019 \text { The authors, under a Creative Commons Attribution- } \\
\text { NonCommercial } 4.0\end{array}$ \\
\hline
\end{tabular}

Corresponding author's email address: alfaintellectual @gmail.com

Recommended citation: Innocent, A. P. \& Eikojonwa, O. (2019). Candidate Selection and the Electoral Prospects of the Peoples' Democratic Party (PDP) in Nigeria: 1999-2015. Review of Politics and Public Policy in Emerging Economies, 1(2), 87-94

\section{Introduction}

A new democratic regime was installed in Nigeria on May 29, 1999 after about two decades of military dictatorship. From 1999 to 2015, the Peoples' Democratic Party (PDP), which is one of the political parties registered in 1998 became the ruling party. Prior to 2015, the party won all the presidential elections and most states and national assembly elections.

While it would be unfair to assert that the PDP did not record any achievement in its operations in country when it was in power, it is instructive to note that a lot of contradictions characterized its operations. Not sooner than later, the party became embroiled in internal crisis. However, the party's stubborn refusal to adhere to some of the resolutions made by the stakeholders with respect to candidate 
selection, plunged it into internal crises and discontent. This resulted in frequent change of the party's leadership through presidential interference, mass defection including those of the founding founders, lack of internal party democracy, especially in its candidate nomination procedure.

The party's unity was undermined as members were entangled in conflicts and legal battles. It became an instance of "things fall apart" as the party which one boasted it would rule for at least one hundred years uninterrupted was defeated after just fifteen years by the opposition All Progressives Congress in the 2015 presidential elections.

The implication is that, for political parties to sustain their electoral strength, they must not stubbornly derail from the doctrines of internal party democracy, particularly with regards to candidate selection which was the greatest undoing of the PDP.

\section{Literature Review}

\subsection{Candidate Selection and the Operations of Political Parties}

A political party can be referred to as a group of like-minded people who join together to achieve political office. In as much as the capturing of power is a crucial intention of political parties, not all of them can aspire to realize that objective; some only strive to have representatives in government (Holmes 2008).

Epstein (1989) avers that candidate selection in a party is absolutely an internal affair regardless of legal regulations. It is a predominantly extra-legal process by which a political party decides which of the persons legally eligible to hold an elective public office will be designated on the ballot and in election communication as its recommended and supported candidate or list of candidates. In view of this, candidate selection is specifically an intra-party affair which occurs almost in its entirety within a particular party and is largely unregulated. There are a few instances of established democracies where the country's laws dictate the conditions for candidate selection. ( Gauja 2006).

The recent trend whereby the rate of judicial involvement in political affairs is on the rise may eventually lead to the accompanying rise in the resolution of intra-party affairs, including candidate selection. Nevertheless, such judicial engagements are still largely restricted to whether or not parties have abided by the guidelines they have put in place for themselves (Gauja 2006).

Liberalizing the process of candidate selection has the prospects of creating a proper democratic profile. In the event that the democratization of the candidate selection process is able to improve the performance of the party at the polls, other parties are likely to follow the trend. Within the party, internal struggle for power can also result in the reform of the method of candidate selection. (Scarrow 2000).

Candidate selection does not only determine the choices that voters are faced with but the composition of parties in the legislature as well as in ruling and opposition parties. Thus, it influences the interests that are likely to be addressed and the eventual policy preferences of the government. To be sure, candidate selection determines the major hallmark of contemporary democratic political culture (Likoti 2005).

\subsection{The Political Consequences of Candidate Selection}

The political impact of candidate selection could be viewed from four basic perspectives. These are participation, representation, competition and responsiveness. All these factors are components of citizens' basic awareness of contemporary representative democracy, that is a form of government whereby the citizens take part in making choices among parties or candidates (participation), who compete with each other in an attempt to be representatives of the people and who are expected to 
exhibit responsiveness to their yearnings and aspirations after being elected. While modern representative government is a national phenomenon, it is still pertinent to understand intraparty activities (Alfa, et al 2017).

\subsection{Participation}

Participation is crucial to democracy. In the representative democracy in the contemporary era, there is universal adult suffrage, that is the generality of the adult citizens exercise their franchise. At the national level, democracy entails inclusiveness. However, participation at the intraparty level requires critical evaluation too. In several democracies, candidate selection methods are increasingly inclusive (Hazan 2002).

In recent time, many parties give the opportunity to their rank and file to participate significantly in all shades of democracies. It has been established that in the event of declining membership, one of the strategies through which citizens are brought back into the party fold by the political elites is by giving them increased roles and sense of belonging in the affairs of the party. Of special prominence in such inclusion is allowing them to take active part in the process of candidate selection (Scarrow 2000).

\subsection{Representation}

There is widespread agreement in political philosophy and political theory that representation does not lend itself to universal interpretation. In other words, the meanings of representation vary and are at times diametrically opposed to each other. This is as a result of different approaches as well as its evolution (Birch 2011).

For an institution to be seen as representative in electoral or recruitment literature the various sub-groups in the society must be reflected in its composition. Such groups are gender, education, class, ethnicity, religion among others (Norris 2006, Gallagher \& Mash 1988). The quality of candidate selection process is not the only determinant factor in representation. Rather, other indices abound and they include inadequate fielding of women candidates (Lovenduski \& Norris 1993).

\subsection{Competition}

In every democratic setting, what features prominently are free competition of interests, values as well as identities. Political parties and the candidates offer themselves as representatives of the various groups, value and identities and struggle for votes from the electorates periodically. Within the parties, competition takes place among the candidate seeking the support of those responsible for selecting them for the general election. This could be the entire voters, members of the party, the delegates of the party, the party elite or a single leader of the party. Intraparty competition is fundamental for the working of the democracy (Schlesinger, 1994).

The above is imperative particularly in societies where interparty competition is not strong. Nevertheless, intraparty competition cannot be entirely a substitute for interparty struggles (Satori 1976). Competition result in accountability and makes leaders responsive to the yearnings and aspirations of those who select them in order to win their favour in subsequent competitions. While competition enhances democracy, in the extreme, it has the potential of constituting a bottleneck to democracy. It could lead to money politics as much money would be deployed to prosecute campaigns and lead to series of corrupt practices (Alfa et al, 2017).

\subsection{Responsiveness}

Responsiveness and representation are mutually reinforcing. Responsiveness invariably implies accountability on the part of elected representatives. Those elected by the electorates are expected to be accountable and responsive to the aspirations of the electorates. Proponents of representative responsiveness posit that representatives must address the needs, demands and interests of those who elected them.

In view of the above, it could be asserted without mincing words that for a method of candidate selection to be seen as democratic, it must fundamentally enhance and facilitate all the four perspectives 
of democracy; a great deal of political participation, representation of all potent social forces and a variety of views, genuine competition for realistic positions on the list of the party's candidates and a valid electoral link that would make the elected representatives address the needs and grievances of the people (Rahat 2011).

Since the return to democratic governance in 1999, the requirements for the establishment and registration of parties in Nigeria remain largely open (Katsina,2016). However, the intraparty activities and management of political parties are characterized by undemocratic and antidemocratic tendencies (Omoruyi 2016). A few rich politicians have hijacked the parties and operate them as their private business to meet their selfish interests thereby truncating the parties' capacity to carry out their functions in the democratic set up. Subsequently, the parties' fundamental roles of interest articulation, aggregation and political education are being profoundly undermined. The result is that parties have become vehicles for actualization of power and primitive capital accumulation. This portends serious setbacks for internal practices within the party and negates internal party democracy and party institutionalization (Omoweh 2012). In view of this, Mba (2011) posits that since the current democratic rule begun in 1999, political parties themselves have not been truly democratic.

A great deal of opinion exists since Nigeria returned to democracy that political parties are expected be democratic not only in their internal goals and objectives but also in their internal operations and organization (Omotola,2010). A crucial look at the operations of the political parties especially during primary elections raises doubt whether they are abiding by the tenets of internal democracy. They are alleged to be disregarding the provisions of their constitutions and disregard due process.

Salih \& Nordlund (2007) contend that at the conventions and congresses of the parties, leaders are elected and candidates are selected through elective positions. Ironically, the outcomes are often predetermined and party bosses tend to have the final say in the process of selection of those to occupy leadership positions. This practices result in perennial internal party conflicts that the country has been subjected to. Party bigwigs are intransigent to allow the enforcement of internal party democracy, a situation that culminate in frequent conflicts and prevents the growth of parties as essential organizations. Over the years, the party bigwigs have developed stamina for frustrating popular aspirants from party positions and stop them from being selected for elective positions.

Omilusi (2016) contends that Nigerian political parties have a variety of strategies to short change people and remove them from the contest of party primaries. These unconventional practices include: coercing people to support a favored candidate while others are prevailed upon to withdraw from the race; zoning the position to the ward, constituency or local government of the anointed candidate to foreclose the chances of contestants from outside the area; violent attacks on the opponents or those who are perceived to be real or imaginary threats to the party barons; use of money to bribe voters or delegates in order to influence their voting behavior and exclude those who cannot sustain the tempo; alteration or falsification of result to produce intended result. In this case the loser could be announced as the winner by polling officials who have already been bribed to manipulate the result.

There is a pervasive believe that political parties have abandoned their traditional roles in Nigeria's democracy and as such constitute a spoke in the wheel of democratic governance. They no longer embark on political education, no more consistent and sustained financial membership as well as regular grassroots meetings except when elections are at hand (Momoh 2016). The virtual disregard of the internal life of political parties is caused by the fact that they have long been seen as private organizations in the purview of liberal theoretical assumption. Parties ought to compete freely in the elections and decide their own internal structures and activities (Salih, 2003).

The implication of the manipulated party primaries since the beginning of the Fourth Republic has been devastating for Nigeria's democracy. Some of these are bitter political feud between political 
"godfathers" and their political "children", barbaric assassination of aspirants and candidates, inter-party violent conflicts, defection, ballot snatching and abduction and protracted judicial processes that ended up annulling the election of those that claimed victory at the polls (Tenuche 2011). The increase in the attacks orchestrated by the "Boko Haram" insurgents in some parts of the country, is a remote consequence of the absence of internal party democracy in the Peoples' Democratic Party (Azazi, 2012, Omoruyi,2016).

\subsection{The Emergence of the Peoples' Democratic Party (PDP)}

The formation of the Peoples' Democratic Party (PDP) could be traced to the fearless step taken by a group of prominent and politically conscious but aggrieved Nigerians christened the G18 in 1997. The group was politically provoked by the militarization of the country's political firmament during the Abacha's regime which was masterminded to facilitate Abacha's civilianization bid. The political clique eventually its number to thirty-four (34). The fundamental craving of the group was the liberalization of the democratic horizon. They gave political withdrawal timetable to Abacha to take an exit from the political scene. Incidentally, Abacha had not aceded to the aspirations of the group before his sudden demise in 1998 (Osumah \& Ikelegbe 2009).

Abacha was succeeded by Abdulsalami Abubakar who gave room for greater participation. Afterwards, several political groups that were denied registration under Abacha built a synergy with the G34 and established the Peoples' Democratic Party (PDP) and was officially registered on July, 1998 (PDP 2011, Odukoya 2012).

\subsection{The Electoral Fortunes of the Peoples' Democratic Party (PDP)}

Between 1999 and 2015, five general elections were conducted. Those elections include presidential, gubernatorial, national assembly and state assembly elections. The 1999 elections signalled significant political breakthrough for the Peoples' Democratic Party The party's victory was repeated in the subsequent electoral contests. However, after 2007, the political influence of the PDP began to wane until it eventually lost to the All Progressives Party (APC) in the general elections of 2015 (Katsina 2016).

\subsection{Factors responsible for the Defeat of the Peoples' Democratic Party (PDP)}

A plethora of factors acted as catalysts in the fluctuation of electoral fortunes of the PDP since it was formed in 1998 and the time it lost power to the PDP in 2015. The fundamental one is the manipulation of candidate selection process. In other words, there was absence of intraparty democracy particularly as it pertains the procedure of nominating candidates for general elections. This culminated in grievances and bitter rivalries some of which became subjects of litigation in quest to seek redress (Kura 2009).

The party also circumvented the rule of law in managing its internal disagreements. This was obvious in the way and manner it managed the crisis that resulted from its re-registration exercise which frustrated the former vice president, Atiku Abubakar out of the party (Adeniyi 2017). The great deal of mistrust among the major stakeholders, propelled by developments such as President Obasanjo's 'third term' bid caused a horrendous schism among members (Akindele 2011, Akubo \& Yakubu 2014).

Another crucial factor which shrank the electoral vigour of the PDP was failure to fulfil campaign promises. Jonathan's popular campaign slogan of " I went to school without shoes and a school bag; vote for me and I would never let you down" really inspired the masses who voted massively for him in 2011. However, four years later, not much had improved in terms of the living conditions of the citizens, infrastructural development and the rate of insecurity became phenomenal (Igbokwe-Ibeto 2016).

The refusal of President Goodluck Jonathan to honour the rotational formula decided by the PDP constituted a clog in the spoke of party's unity and cohesiveness (Ojougboh 2015). Former President Obasanjo's brazen criticism emboldened the opposition and for those still indecisive, they were convinced to believe defeating an incumbent president was feasible. Obasanjo helped to undermine 
Jonathan's popularity both within the PDP and among the generality of Nigerians as the elections approached. Obasanjo's opposition gave an added impetus to the disposition of the United States and British government in their presentiment that Jonathan's second term could plunge into chaos. Obasanjo, through his body language encouraged the corporate Nigeria who were characteristically in the habit of supporting the incumbents with huge finance to the exclusion of the opposition to build confidence in Buhari. Buhari then had enormous resources to embark on campaign across Nigeria and in the end defeated the incumbent president Good luck Jonathan in the 2015 elections (Adeniyi 2017, Katsina 2016).

\section{Conclusion}

Political parties are important institutions in democratic societies. Nigeria's political antecedents has shown that political parties have failed to make expected input to democratic development and stability. Since the installation of democratic governance, political parties have not been able to make a radical departure from the tradition. In the case of the Peoples' Democratic Party, its affairs have been characterised by absence of intraparty democracy. The fallout of this is internal party bickering particularly in the candidate selection activities and this has marred the party's unity and electoral prospects. Other factors include corruption, non-redemption of campaign promises, inability to tackle insecurity, recalcitrance of President Jonathan to adhere to the party's rotational formula, effective opposition by the All Progressives Congress among others.

It behoves one to note that from the various exposition so far, it could be said without mincing words that candidate selection could make or mar a party's unity, internal cohesiveness and electoral prospects as evidenced in the affairs of the Peoples' Democratic Party. It is, therefore, pertinent the political parties should adopt a transparent approach in selecting their candidates for internal party positions and general elections.

Besides the above, It could be contended that for a political party to be able to attract the interest and support of the electorates and retain its popularity, it should be ideologically-based, those who rose to power on its platform should be faithful to their campaign promises, the stakeholders should observe the basic tenets internal party democracy and follow arrangements within the party such as the rotational arrangement.

The assertion of Schattschneider (1942:15) on the pivotal role of candidate selection still remains sacrosanct. As he puts:

The bid for power through election has another consequence: it makes the nomination the most important activity of the party. In an election, the united front of the party is expressed in terms of nominations. For this reason, nominations have become the distinguishing mark of modern political parties; if a party cannot make nominations it ceases to be a party...The nomination may be made by a congressional caucus, a delegate convention, a mass meeting, a cabal, an individual or a party election. The test is, does it bind? Not, how as it done? Unless the party makes authoritative and effective nominations, it cannot stay in business for dual or multiple party candidates mean certain defeat. As far as elections are concerned, the united front of the party, the party concentration of numbers can be brought about only by a binding candidate nomination. The nomination process, thus has become the crucial process of the party. The nature of the nominating process determines the nature of the party; he who make the nomination is the owner of the party. This is therefore one of the best points at which to observe the distribution of power within the party. 


\section{REFERENCES}

Adeniyi, O. (2017). Against the run of play: How an incumbent president was defeated in Nigeria. BookBaby

Akindele,S.T (2011) Intra and Inter-party post election crisis/ feud management in a pluralistic democracy: An X-ray of the Nigeria's political landscape. African Journal of Political Science and International Relations 5(6) 287-330.

Akubo, A. A. and Yakubu, A. U. (2014). Political Parties and Democratic Consolidation in Nigeria"s Fourth Republic. Global Journal of Political Science and Administration, Vol.2, No.3, pp.79108

Alfa, P.I, Yusoff, K.Z, Rajanthiran, S.P (2017). Political Parties and the Quest for Democratic Sustenance in Nigeria's Fourth Republic. International Journal of Public Administration and Management, Vol. 4(1) 58-63.

Azazi, O. (2012). NSA Blames PDP for Boko Haram Crisis. Weeklytrust. com. ng, 7.

Benevenisti, E. (2002). Party Primaries as Collective Action with Constitutional Ramifications: Israel as a Case Study. Theoretical Inq. L., 3, 175.

Birch, S. (2011). Electoral malpractice. Oxford University Press on Demand.

Epstein, L. D. (1988). Will American Political Parties Be Privatized. JL \& Pol., 5, 239.

EU EOM (2007). Nigeria: Final Report of Gubernatorial and State Houses of Assembly Elections and Presidential and National Assembly Elections 2007. European Union Election Observation Mission (EUEOM).Evidence from Nigeria, African Security, DOI: 10.1080/19392206.2017.1305860

Gallagher, M., \& Marsh, M. (1988). Candidate selection in comparative perspective: The secret garden of politics (Vol. 18). Sage Publications Ltd.

Gauja, A. (2006). Enforcing Democracy?: Towards a Regulatory Regime for the Implementation of Intra-party Democracy. Democratic Audit of Australia, Australian National University.

Hazan, R. Y. (1997). The 1996 intra-party elections in Israel: Adopting party primaries. Electoral Studies, 16(1), 95-103.

Holmes, P. (2008). Introducing Politics for AS level. Polity.

Igbokwe-Ibeto, J. C., Osakede, O. K., Nkomah, B. B., \& Kinge, F. R. (2016). Election and democratic consolidation in Nigeria: an analysis of the 2015 general elections. Arabian Journal of Business and Management Review (Oman Chapter), 5(10), 1.

Katsina, A. M. (2016). Peoples Democratic Party in the Fourth Republic of Nigeria: Nature, Structure, and Ideology. SAGE Open, 6(2), 2158244016651910.

Kura, S. B. (2008). African Ruling Political Parties and the Making of 'Authoritarian'Democracies: Extending the Frontiers of Social Justice in Nigeria. African Journal on Conflict Resolution, 8(2), 63-101.

Likoti, F. J. (2005). Investigating Intra-party Democracy in Lesotho: Focus on Basutoland Congress Party and Basotho National Party.

Lovenduski, J., \& Norris, P. (2003). Westminster women: the politics of presence. Political studies, 51(1), 84-102.

Maiyo, J. (2008). POLITICAL PARTIES AND INTRA-PARTY DEMOCRACY IN EAST AFRICA From Representative to Participatory Democracy. MPhil Thesis, Africa Studies Centre, Leiden University.

Mbah, P. (2011). Party defection and democratic consolidation in Nigeria, 1999-2009. Afro Asian Journal of Social Sciences, 2(2.3), 1-21.

Momoh, A. (2010). Democracy And Elections: Myths, Illusions And Realities" being 3rd Annual Law and Social Development Lecture delivered at Airport Hotel Ikeja. October, 25, 2010.

Norris, P (ed) (2003) Comparing Democracies 2: New Challenges in the Study of Elections Obasanjo, O. A (2015). My Watch. U.K: Amazon.

Odukoya, A. (2012). Party system and political conflicts in Nigeria's fourth republic. Nigeria's Democratic Experience in the Fourth Republic since 1999: Policies and Politics, 127. 
Ojuogbo, C (2015). Jonathan Lost Because He Breached Zoning Arrangement in Nigeria. The Herald, July 12.

Omilusi, M (2015) The Nuances and Nuisances of Party Defection in Nigeria's Fourth Republic. International Journal of Multidisciplinary Academic Research. Vol.3 No 4. pp94-106.

Omoruyi, A (2016). Internal Party Conflicts: The Effects of Internal Party Democracy in Nigeria's Political Parties- The Forward. Retrieved Fromhttps://www.linkedin.com/pulse/internal party conflicts-effect-lack-democracy-nigeria-aigbe

Omotola, J. S. (2010). Political Parties and the Quest for Political Stability in Nigeria. Taiwan Journal of Democracy, 6(2).

Omoweh, D. A. (2012). Deconstructing the Democratic Developmental State: Blocked

Democratization and Political Parties in Nigeria and South Korea. The Feasibility of the Democratic Developmental State in the South, 41.

Osumah, O., \& Ikelegbe, A. (2009). The peoples democratic party and governance in Nigeria, 19992007. Journal of Social Sciences, 19(3), 185-199.

PDP (2011) Manifesto of the Peoples' Democratic Party. Retrieved from peoplesdemocraticparty.com.ng/?page-id-72.

Salih, M. A. R. M. (2003). African political parties: Evolution, institutionalism and governance. Pluto Press..

Salih, M. A. R. M., \& Nordlund, P. (2007). Political parties in Africa: Challenges for sustained multiparty democracy (p. 143). Stockholm, Sweden: International Idea.

Scarrow, S. (2000) 'Parties without members?', in Dalton, R et al (eds) Parties without partisans: Political Change in Advanced Industrial Democracies. New York: Oxford University Press, pp 79-102.

Schattschneider, E. E. (1960). Party government. Transaction Publishers.

Schlesinger, J. A. (1994). Political parties and the winning of office. University of Michigan Press.

Tenuche, M. (2011). The albatross called primary elections and political succession in

Nigeria. Canadian Social Science, 7(4), 121-130. 